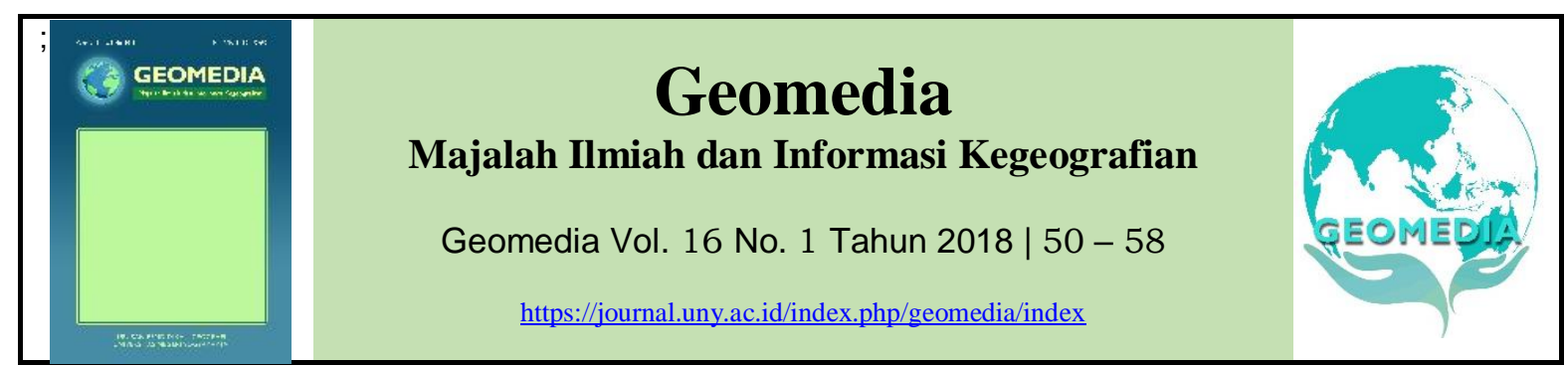

\title{
Analisis Spasial Tingkat Kerawanan Demam Berdarah Dengue untuk Pemetaan Daerah Prioritas Penanganan Menggunakan Sistem Informasi Geografis di Kecamatan Prambanan Kabupaten Klaten
}

\author{
Achmad Fadhilah ${ }^{\text {a, }}{ }^{*}$, Dyah Respati Suryo Sumunar ${ }^{\text {a, } 2}$ \\ a Jurusan Pendidikan Geografi Universitas Negeri Yogyakarta, Yogyakarta, Indonesia \\ 1 geofadhil94@gmail.com*; 2dyah_respati@uny.ac.id \\ *korespondensi penulis
}

\begin{tabular}{ll}
\hline Informasi artikel & A B S T R A K \\
\hline Kata kunci: & Penelitian ini bertujuan untuk mengetahui tingkat kerawanan demam \\
Tingkat Kerawanan DBD & berdarah dengue (DBD), penentuan daerah prioritas penanganan DBD, \\
Prioritas Penanganan DBD & Pan keterkaitan antara hujan terhadap kasus DBD di Kecamatan \\
Sistem Informasi Geografis & deskriptif dengan pendekatan kuantitatif berbantuan Sistem Informasi \\
Kecamatan Prambanan & Geografis. Variabel penelitian meliputi: (1) kepadatan penduduk, (2) \\
& kepadatan permukiman, (3) penggunaan lahan, (4) jarak dari sungai, (5) \\
& jarak dari tempat penampungan sampah sementara, dan (6) angka \\
& kejadian DBD. Metode pengumpulan data yang digunakan: observasi, \\
& interpretasi citra penginderaan jauh, dan dokumentasi. Teknik analisis \\
& data yang digunakan adalah skoring, buffering, dan overlay. Hasil \\
& penelitian: terdapat tiga kelas tingkat kerawanan DBD yaitu tingkat \\
kerawanan tinggi (321,37 ha), sedang (1806,55 ha), dan rendah (544,69 & ha). Daerah prioritas utama penanganan DBD di Kecamatan Prambanan \\
berdasarkan tingkat kerawanannya adalah Desa Kemudo dan Desa & Kebondalem Lor. Jenis penanganan DBD yang diprioritaskan adalah \\
pemberantasan sarang nyamuk dan menjaga kebersihan lingkungan. & Curah hujan bulanan ternyata tidak berpengaruh signifikan terhadap \\
kejadian DBD.
\end{tabular}

\section{Keywords:}

Level DHF susceptibility

DHF Handling Priority Area

Geographic Information System

Prambanan Sub-district

\section{A B S T R A C T}

This study aims to determine the level of vulnerability of dengue hemorrhagic fever (DHF), determination of priority areas for handling DHF, and the relationship between rain and dengue cases in Prambanan Subdistrict, Klaten Regency. This research is a descriptive study with a quantitative approach assisted by Geographic Information Systems. Research variables include: (1) population density, (2) settlement density, (3) land use, (4) distance from the river, (5) distance from temporary waste shelter, and (6) DHF incidence rate. Data collection methods used include: observation, imagery interpretation, and documentation. Data analysis techniques used are scoring, buffering, and overlay. The results: there are three classes of DHF susceptibility levels, namely high vulnerability (321.37 ha), moderate (1806.55 ha), and low (544.69 ha). The main priority area for handling DHF in Prambanan Sub-district based on its vulnerability is Kemudo Village and Kebondalem Lor Village. The priority type of DHF handling is eradication of mosquito nests and maintaining environmental cleanliness. Monthly rainfall turns out to have no significant effect on the incidence of DHF 


\section{Pendahuluan}

Kejadian Demam Berdarah Dengue (DBD) di Kabupaten Klaten terus meningkat dalam kurun waktu 4 tahun terakhir. Berdasarkan data Dinas Kesehatan Kabupaten Klaten, pada tahun 2012 terdapat 82 kasus dengan jumlah kematian sebanyak 2 orang. Tahun 2013 kasus DBD meningkat menjadi 336 orang dengan jumlah kematian sebanyak 5 orang. Tahun berikutnya sedikit menurun menjadi 260 kasus (Dinkes Kab. Klaten, 2014). Terjadi kenaikan lagi pada tahun 2015 menjadi 525 kasus dengan kasus kematian sebanyak 26 orang. Hingga akhir bulan Februari tahun 2016 tercata sudah terdapat 145 kasus DBD dan 6 diantaranya meninggal dunia (Ucu, 2016).

Dinas Kesehatan Kabupaten Klaten juga menetapkan 56 desa dari 21 kecamatan endemis DBD. Kecamatan Prambanan adalah salah satu kecamatan dengan angka kematian DBD tertinggi. Pada awal tahun 2016, delapan desa di Kecamatan Prambanan dinyatakan endemis DBD (http://radarsolo.co.id). Berdasarkan hasil observasi di Puskesmas Kebondalem Lor, Prambanan hingga bulan Oktober 2016 telah terjadi kasus DBD sebanyak 65 kasus di wilayah kerja Puskesmas tersebut. Data di Puskesmas Prambanan menunjukkan kasus DBD sebanyak 36 kasus di wilayah kerja Puskesmas Prambanan.

Adanya kejadian DBD di suatu daerah dipengaruhi oleh kondisi lingkungan fisik dan sosialnya. Kondisi tempat yang terdapat banyak tampungan air terbuka cenderung memiliki potensi DBD yang tinggi. Hal ini disebabkan oleh vektor DBD yakni nyamuk Aedes aegypti hidup dan berkembangbiak pada tampungantampungan air. Tampungan air dapat dijumpai pada beberapa benda dan tempat antara lain botol bekas, ember, ban luar, kolam renang, kolam/bak mandi dan benda-benda bekas di Tempat Penampungan Sampah (TPS).

Selain faktor fisik, penyebaran DBD juga dipengaruhi oleh faktor sosial seperti jumlah dan kepadatan penduduk. Tingginya jumlah dan tingkat kepadatan penduduk cenderung menyebabkan suatu wilayah semakin rawan terhadap DBD. Kepadatan penduduk turut menunjang atau sebagai salah satu faktor risiko penularan penyakit DBD (Fathi dkk, 2005:4). Semakin tinggi tingkat kepadatan penduduk maka sasaran gigitan nyamuk semakin banyak dan jarak antar aktivitas manusia semakin dekat sehingga memungkinkan dijangkau oleh nyamuk
Aedes. Kepadatan penduduk yang tinggi juga berpengaruh terhadap penggunaan barang yang dapat menampung air menjadi semakin banyak. Permukiman yang padat menunjukkan banyaknya penduduk di dalamnya. Semakin banyak penduduk maka semakain rawan terkena DBD. Jumlah penduduk Kabupaten Klaten pada tahun 2013 mencapai 1.316.907 jiwa dengan tingkat kepadatan penduduk sebesar $2.009 \mathrm{jiwa} / \mathrm{km} 2$ (Dinkes Kab Klaten, 2014). Sedangkan kepadatan penduduk di Kecamatan Prambanan Kabupaten Klaten sebesar 1986 jiwa/km (BPS, 2016). Angka tersebut tergolong tinggi untuk tingkat kecamatan.

Upaya pencegahan dan penangan telah dilakukan oleh Dinas Kesehatan Kabupaten Klaten untuk mengurangi angka kasus DBD. Upaya yang dilakukan antara lain: melakukan penyuluhan dan sosialisasi kepada masyarakat agar menjaga kebersihan lingkungan, melakukan Pemberantasan Sarang Nyamuk (PSN) untuk mencegah perkembangbiakan nyamuk, menutup tempat dan barang yang dapat menampung air, melakukan pengecekan terhadap perkembangan jentik nyamuk dan pemberian obat pencegah perkembangbiakan jentik nyamuk. Selain upaya secara langsung di lapangan, pemberantasan DBD juga memerlukan skala prioritas daerah penanganan. Hal ini dikarenakan tingkat kerawanan DBD di setiap tempat berbeda-beda. Menurut Sumarmo (1988: 57) salah satu langkah dasar untuk menentukan keputusan pemberantasan DBD adalah dengan menentukan daerah prioritas secara ekologi dan membuat urutan prioritas daerah itu. Penentuan skala prioritas didasarkan pada tingkat kerawanan kasus DBD pada tiap-tiap desa. Tingkat kerawanan DBD dapat diketahui melalui variabelvariabel kepadatan penduduk, jarak terhadap sungai, jarak terhadap TPS, dan jumlah kejadian DBD.

Aplikasi Sistem Informasi Geografis (SIG) dapat digunakan sebagai salah satu metode untuk mencapai tujuan tersebut. SIG merupakan sistem informasi yang dapat digunakan untuk mengolah data keruangan dan atribut menjadi informasi baru berbasis ruang (spasial). SIG dapat digunakan sebagai alat bantu dalam kajian geografi. Kemampuan SIG dapat menganalisis gejala di permukan bumi dengan data-data fenomena tertentu. Analisis spasial yang dilakukan oleh SIG dapat dijadikan sebagai dasar yang kuat bagi suatu pengambilan keputusan atau pembuatan suatu kebijakan (Prahasta, 2014). Dalam hal ini 
analisis SIG dapat digunakan dalam mengkaji tingkat kerawanan DBD. Faktor-faktor yang memengaruhi penyebaran DBD dapat diolah menggunakan SIG untuk menghasilkan informasi tingkat kerawanan DBD. Informasi tentang tingkat kerawanan DBD ini dapat digunakan dalam kebijakan dan menentukan skala prioritas lokasi penanganan DBD. Penentuan skala prioritas bertujuan untuk mendahulukan dan memprioritaskan lokasi dengan tingkat kerawanan DBD yang tinggi dalam upaya penanganan DBD sehingga lebih efektif dan efisien. Kajian kejadian DBD di Kecamatan Prambanan Kabupaten Klaten perlu dilakukan dengan memanfaatkan SIG.

\section{Metode}

Penelitian ini bertujuan untuk mengetahui tingkat kerawanan DBD untuk prioritas penanganan di Kecamatan Prambanan Kabupaten Klaten. Metode penelitian yang digunakan untuk mencapai tujuan tersebut adalah metode deskriptif dengan pendekatan kuantitatif berbantuan aplikasi Sistem Informasi Geografis (SIG). Tingkat kerawanan DBD ditentukan berdasarkan pada variabel-variabel yang memengaruhi timbulnya kasus DBD. Varibelvariabel yang digunakan antara lain: penggunaan lahan, kepadatan penduduk, kepadatan permukiman, jarak dari sungai, jarak dari dari Tempat Pembuangan Sampah Sementara (TPS) dan angka kejadian DBD.

Populasi dalam penelitian ini seluruh wilayah administratif Kecamatan Prambanan Kabupaten Klaten yang terdiri dari objek fisik dan non fisik. Objek fisik terdiri dari penggunaan lahan, kepadatan permukiman, jaringan sungai, dan lokasi TPS. Sedangkan objek nonfisik berupa kejadian DBD dan kepadatan penduduk.

Sampel dalam penelitian ini hanya digunakan untuk menguji tingkat akurasi interpretasi citra variabel penggunaan lahan. Sampel diperoleh dari hasil interpretasi citra Google Maps dan pengambilan titik sampel langsung di lapangan. Jumlah sampel ditentukan dengan menggunakan rumus Fitzpatrick Lins (McCoy, 2005:21). Jumlah sampel untuk uji akurasi hasil intepretasi penggunaan lahan ditentukan sebanyak 46 sampel. Teknik analisis yang digunakan adalah analisis SIG dengan teknik buffering, skoring, dan overlay, serta analisis korelasi.

\section{Hasil dan pembahasan Daerah penelitian}

Kecamatan Prambanan merupakan salah satu kecamatan yang berada di Kabupaten Klaten, Provinsi Jawa Tengah. Secara astronomi, Kecamatan Prambanan terletak pada 110.20 110.45 BT dan 7.30 - 7.46 LS. Luas wilayah Kecamatan Prambanan adalah 24,43 $\mathrm{km}^{2}$ (BPS Kab Klaten, 2016). Kecamatan Prambanan di sebelah utara berbatasan dengan Kecamatan Manisrenggo, di sebelah timur dengan Kecamatan Gantiwarno dan Jogonalan, serta di sebelah selatan dan barat berbatasan dengan wilayah Provinsi DIY. Kecamatan Prambanan terdiri dari 16 desa yaitu Pereng, Kotesan, Sengon, Kebondalem Kidul, Cucukan, Sanggrahan, Tlogo, Bugisan, Geneng, Kemudo, Taji, Kokosan, Kebondalem Lor, Brajan, Randusari, dan Joho (Gambar 1).

Dilihat dari aspek fisiografi, wilayah Kecamatan Prambanan berada pada dataran rendah di sebelah selatan Gunung Merapi. Ketinggian tempat rata-rata Kecamatan prambanan adalah 146 meter dpal. Secara fisiografis wilayah Kecamatan Prambanan dibatasi oleh Pegunungan Selatan di sebelah Selatan dan Sungai Opak di sebelah Barat (BPS Kab Klaten, 2016). Secara litologi, sebagian besar wilayah Kecamatan Prambanan merupakan bagian dari formasi batuan Gunungapi Merapi. Sementara itu sebagian diantaranya merupakan endapan aluvium tua, yaitu pada bagian yang terletak di sisi selatan. Sebagian kecil lainnya di sebelah tenggara termasuk dalam formasi Kebobutak. Wilayah Kecamatan Prambanan juga berada di atas sesar Opak yang aktif. Kedudukan yang berada di atas sesar aktif ini menyebabkan wilayah Kecamatan Prambanan rawan terhadap gempabumi (BPS Kab Klaten, 2016). Secara klimatis, klim di Kecamatan Prambanan termasuk tipe iklim D menurut klasifikasi Schmidt-ferguson yaitu kategori sedang.

Jumlah penduduk Kecamatan Prambanan pada tahun 2014 sebanyak 48.521 jiwa dengan kepadatan penduduk $1986 \mathrm{jiwa} / \mathrm{km}^{2}$. Desa Kemudo memiliki jumah penduduk terbanyak yaitu 5147 jiwa. Desa Cucukan memiliki jumlah penduduk paling sedikit yaitu 1715 jiwa. Sementara dari aspek kepadatan penduduk, Desa Kebondalem kidul memiliki kepadatan penduduk tertinggi yaitu sebesar $3425 \mathrm{jiwa} / \mathrm{km}^{2}$. Sedangkan kepadatan penduduk terendah terdapat di Desa Cucukan yaitu sebesar 1132 jiwa/km². 


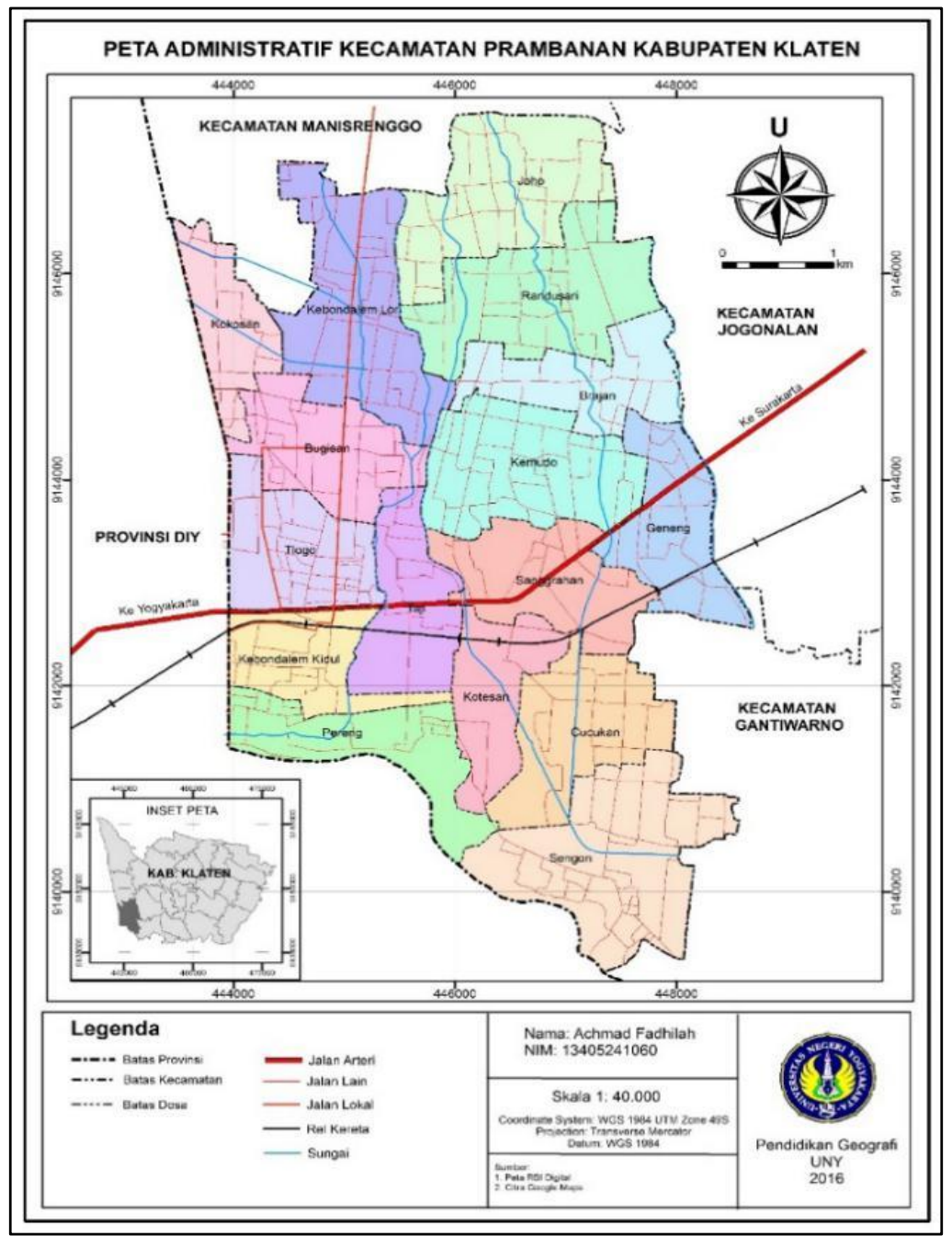

Gambar 1. Peta Adminstratif Kecamatan Prambanan Kab. Klaten

\section{Persebaran Kejadian DBD di Kecamatan Prambanan}

Diantara 26 kecamatan yang ada di Kabupaten Klaten, Kecamatan Prambanan merupakan wilayah yang paling banyak mengalami kejadian DBD di Kabupaten Klaten. Data dari Puskesmas Prambanan, Puskesmas Kebondalem Lor, dan survei lapangan menunjukkan bahwa pada tahun 2016 terdapat 105 kejadian DBD di wilayah tersebut.

Kejadian DBD di Kecamatan Prambanan pada tahun 2016 dijumpai di seluruh desa yang berjumlah 16 desa. Kejadian DBD banyak ditemukan pada desa yang tergolong lingkungan desa perkotaan, yakni: Desa Taji, Tlogo, dan Kebondalem Kidul. Ketiga desa tersebut masingmasing terdapat 16 kasus, 14 kasus, dan 11 kasus. Ketiga desa tersebut juga berada di bagian tengah wilayah Kecamatan Prambanan. Kejadian DBD dengan jumlah lebih sedikit terdapat desadesa di sekitar daerah perkotaan yakni di Desa Pereng dengan 8 kejadian, Kemudo dengan jumlah 9 kejadian, Kebondalem Lor dan Geneng berjumlah 8 kejadian (Gambar 2).

Penderita DBD di Kecamatan Prambanan pada tahun 2016 paling banyak berasal dari kelompok umur 10-14 tahun yaitu sebanyak 25 orang. Selanjutnya data jumlah penderita dari masing-masing kelompok umur adalah sebagai berikut: (1) kelompok umur 0-4 tahun sebanyak 9 orang, (2) kelompok umur 5-9 tahun 21 orang, (3) kelompok umur 15-19 tahun 18 orang, (4) kelompok umur 20-24 10 orang, (5) kelompok umur 25-29 tahun 6 orang, (6) kelompok umur 3034 tahun 8 orang, (7) kelompok umur 35-39 2 orang, (8) kelompok umur 40-44 tahun dan 45-49 tahun masing-masing sebanyak 1 orang dan 2 orang, (9) kelompok umur 60-64 2 orang, (10) dan kelompok umur 55-59 tahun sebanyak 1 orang. Penderita DBD pada kelompok umur 50-54 tahun dan di atas 65 tahun tidak dijumpai. Data kelompok umur penderita DBD tersebut juga menunjukkan bahwa penderita DBD umumnya adalah penduduk berusia 14 tahun ke bawah. 


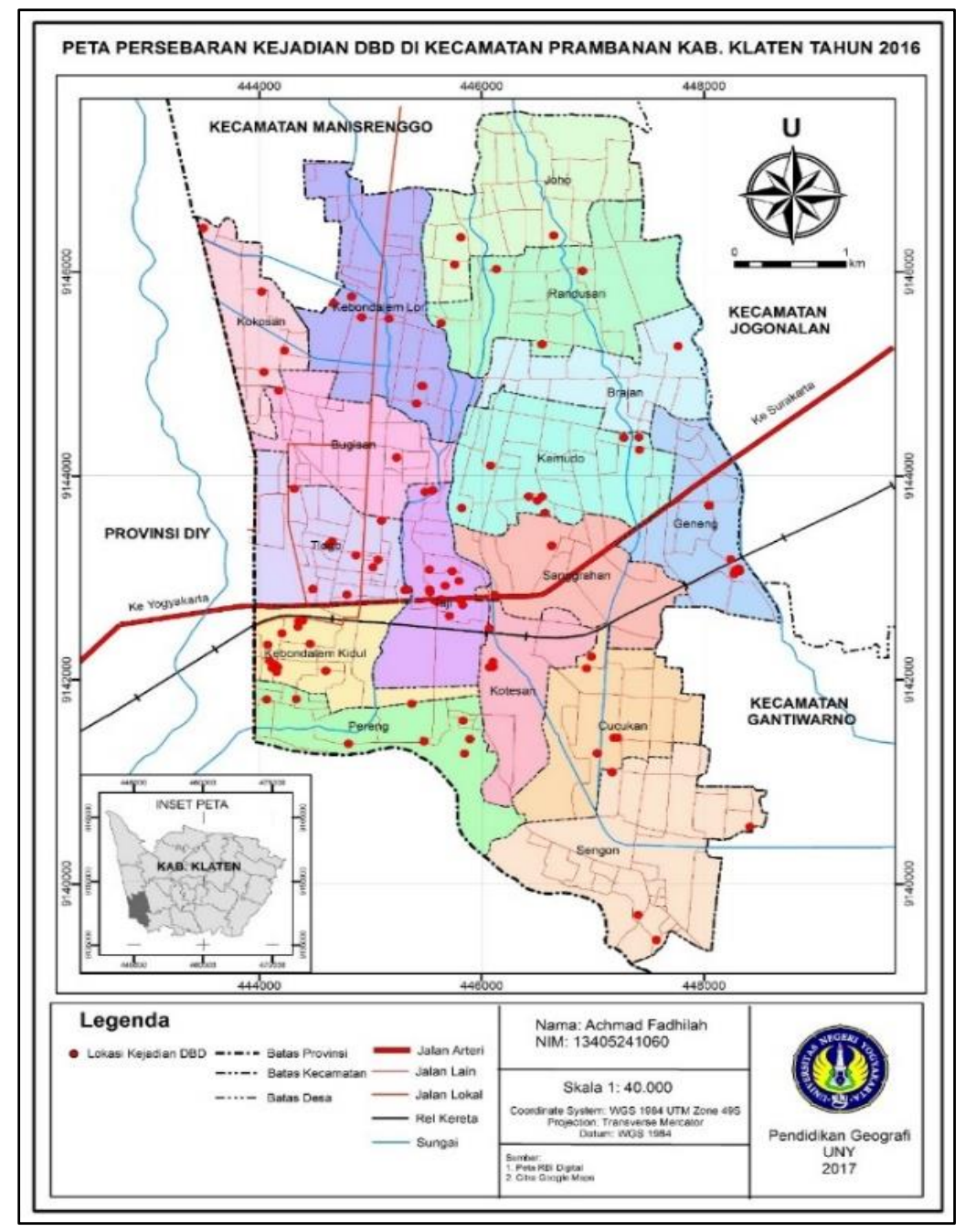

Gambar 2. Peta Persebaran kejadian DBD di Kecamatan Prambanan Kab. Klaten tahun 2016

Ditinjau dari jenis kelamin penderita DBD, jumlah penderita yang berjenis kelamin laki-laki sebanyak 50 orang atau $47,62 \%$ dari jumlah total. Sementara itu penderita DBD yang berjenis kelamin perempuan sebanyak 55 orang atau $52,38 \%$ dari jumlah total. Komposisi ini menunjukkan terdapat jumlah yang relatif berimbang antara laki-laki dan perempuan yang menjadi penderita DBD di Kecamatan Prambanan tahun 2016. Tidak ada kecenderungan jenis kelamin tertentu yang lebih banyak menjadi penderita DBD.

Dilihat dari waktu kejadiannya, hingga bulan Oktober tahun 2016 kejadian DBD di Kecamatan Prambanan paling banyak terjadi pada bulan Maret yaitu sebanyak 17 kejadian atau $16,19 \%$ dari total kejadian. Kejadian DBD di Kecamatan Prambanan pada bulan-bulan lainnya adalah sebagai berikut. (1) pada bulan Januari terdapat 8 kejadian, (2) bulan Februari 10 kejadian, (3) bulan April 13 kejadian, (4) bulan Mei 12 kejadian, (5) bulan Juni 6 kejadian, (6) bulan Juli 12 kejadian, (7) bulan Agustus 7 kejadian, (8) bulan September 8 kejadian, (9) bulan Oktober 5 kejadian, (10) bulan November 3 kejadian, dan (11) bulan Desember terjadi 4 peristiwa DBD. Data ini menunjukkan bahwa tidak terdapat kecenderungan kejadian DBD pada periodeperiode tertentu, misalnya berkaitan dengan musim penghujan, musim kemarau, atau pergantian musim. Pada periode pergantian tahun dimana curah hujan relatif tinggi ternyata jumlah kejadian DBD tidak selalu tinggi. Sebagai contoh pada Bulan Februari terdapat 10 kejadian dan Maret 17 kejadian, namun pada bulan November hanya 3 kejadian dan Desember hanya 4 kejadian DBD. Sebaliknya, pada sekitar pertengahan tahun ketika curah hujan lebih rendah ternyata juga dijumpai jumlah kejadian DBD yang banyak misalnya pada Bulan Mei dan Juli. 


\section{Tingkat kerawanan Demam Berdarah Dengue di Kecamatan Prambanan}

Sebagaimana telah dijelaskan pada bagian awal, terdapat dua faktor yang mempengaruhi kejadian DBD yaitu faktor lingkungan dan kondisi demografis. Kedua faktor ini dijadikan sebagai dasar dalam penentuan tingkat kerawanan DBD di Kecamatan Prambanan. Selain kedua faktor tersebut juga digunakan data kejadian DBD dalam penentuan tingkat kerawanan, sehingga model kerawanan juga mengandung unsur kejadian DBD. Variabel faktor lingkungan antara lain meliputi: kepadatan permukiman, penggunaan lahan, jarak dari sungai, dan jarak dari TPS. Adapun kondisi demografis digambarkan oleh tingkat kepadatan penduduk. Variabel yang berkaitan dengan kejadian DBD dinilai berdasarkan angka kejadian DBD untuk setiap desa desa.

Untuk menentukan skor area/poligon berdasarkan variabel-variabel digunakan analisis overlay dengan skoring. Proses overlay dan skoring menggunakan aplikasi ArcMap 10.3. Layer yang ditumpangsusunkan merupakan layer dengan atribut variabel-variabel kerawanan yang telah diberi skor. Dengan demikian setiap poligon memiliki nilai/skor. Proses overlay dengan fungsi intersect menghasilkan layer baru yang memuat informasi atribut kerawanan dan skornya. Selanjutnya untuk menentukan kelas kerawanan dibuat kelas kerawanan dengan memperhatikan selisih antara skor tertinggi dan terendah. Area dengan interval skor yang sama dikelompokkan dalam satu kelas yang sama. Kelas kerawanan ditentukan dalam tiga kelas yaitu kelas kerawanan tinggi, kelas kerawanan sedang, dan kelas kerawanan rendah. Skor terendah dalam analisis skoring adalah 3 dan skor tertinggi adalah 18, dengan demikian dapat ditentukan skor masingmasing kelas pada rentang 5 angka. Area/poligon dengan skor 13-18 termasuk ke dalam tingkat kerawanan tinggi, skor 8-12 termasuk tingkat kerawanan sedang, dan skor 3-7 dikategorikan sebagai kelas tingkat kerawanan rendah. Dari skor yang diperoleh masing-masing poligon selanjutnya dapat dihitung luasnya dengan aplikasi ArcMap 10.3 sehingga diperoleh luas wilayah dari masing-masing kelas kerawanan. Tingkat kerawanan dan area cakupan masingmasing kelas hasil analisis overlay dan skoring ditunjukkan oleh Tabel 1.
Tabel 1. Luas area yang rawan penyakit DBD

\begin{tabular}{|c|c|c|c|}
\hline Interval & Kelas & $\begin{array}{l}\text { Luas } \\
\text { (ha) }\end{array}$ & $\%$ \\
\hline $13-18$ & Tinggi & 351,37 & 13,00 \\
\hline $8-12$ & Sedang & 1806,55 & 66,85 \\
\hline \multirow[t]{2}{*}{ 3- 7} & Rendah & 544,69 & 20,15 \\
\hline & Jumlah & 2702,60 & 100,00 \\
\hline
\end{tabular}

Sumber: Hasil Analisis Data, 2017

Berdasarkan Tabel 1, kelas kerawanan sedang paling banyak dijumpai sementara kelas kerawanan tinggi paling sedikit dijumpai di daerah penelitian. Luas area masing-masing kelas berturut-turut adalah sebagai berikut. (1) tingkat kerawanan tinggi mencakup area seluas 351,37 hektar atau $13 \%$ dari luas Kecamatan Prambanan. (2) tingkat kerawanan sedang mencakup area seluas 1806,55 hektar atau $66,85 \%$ wilayah. (3) tingkat kerawanan rendah mencakup area seluas 544,69 hektar atau 20,15\% dari wilayah Kecamatan Prambanan. Jumlah area dengan tingkat kerawanan DBD tinggi yang paling luas adalah di Desa Kebondalem Lor yakni seluas 57,1 hektar. Desa Joho, Randusari, dan Brajan tidak terdapat area yang termasuk kerawanan DBD tinggi.

Pada area tingkat kerawanan DBD sedang diperoleh hasil yang berbeda. Desa yang yang memiliki area terluas adalah Desa Joho yaitu desa yang terletak paling utara wilayah Kecamatan Prambanan dengan luas cakupan 185,21 hektar. Desa yang memiliki luas area paling kecil untuk kerawanan DBD sedang adalah Desa Brajan yakni seluas 52,3 hektar. Untuk kelas kerawanan DBD rendah, Desa Sengon memiliki cakupan paling luas yaitu 123 hektar. Sementara itu Desa Tlogo, Kebondalem Lor, dan Kebondalem Kidul tidak memiliki area yang termasuk ke dalam tingkat kerawanan DBD tinggi. Data dan deskripsi di atas menunjukkan bahwa kejadian DBD berpotensi tinggi terjadi di daerah dengan kerawanan DBD tinggi. Persebaran spasial tingkat kerawanan DBD di Kecamatan Prambanan ditunjukkan oleh Gambar 3. Tingkat kerawanan sedang tersebar secara merata di seluruh Kecamatan Prambanan, sementara tingkat kerawanan tinggi dan rendah relatif mengelompok dan ada pula bagian yang terisolir namun dengan cakupan area yang tidak terlalu luas. 


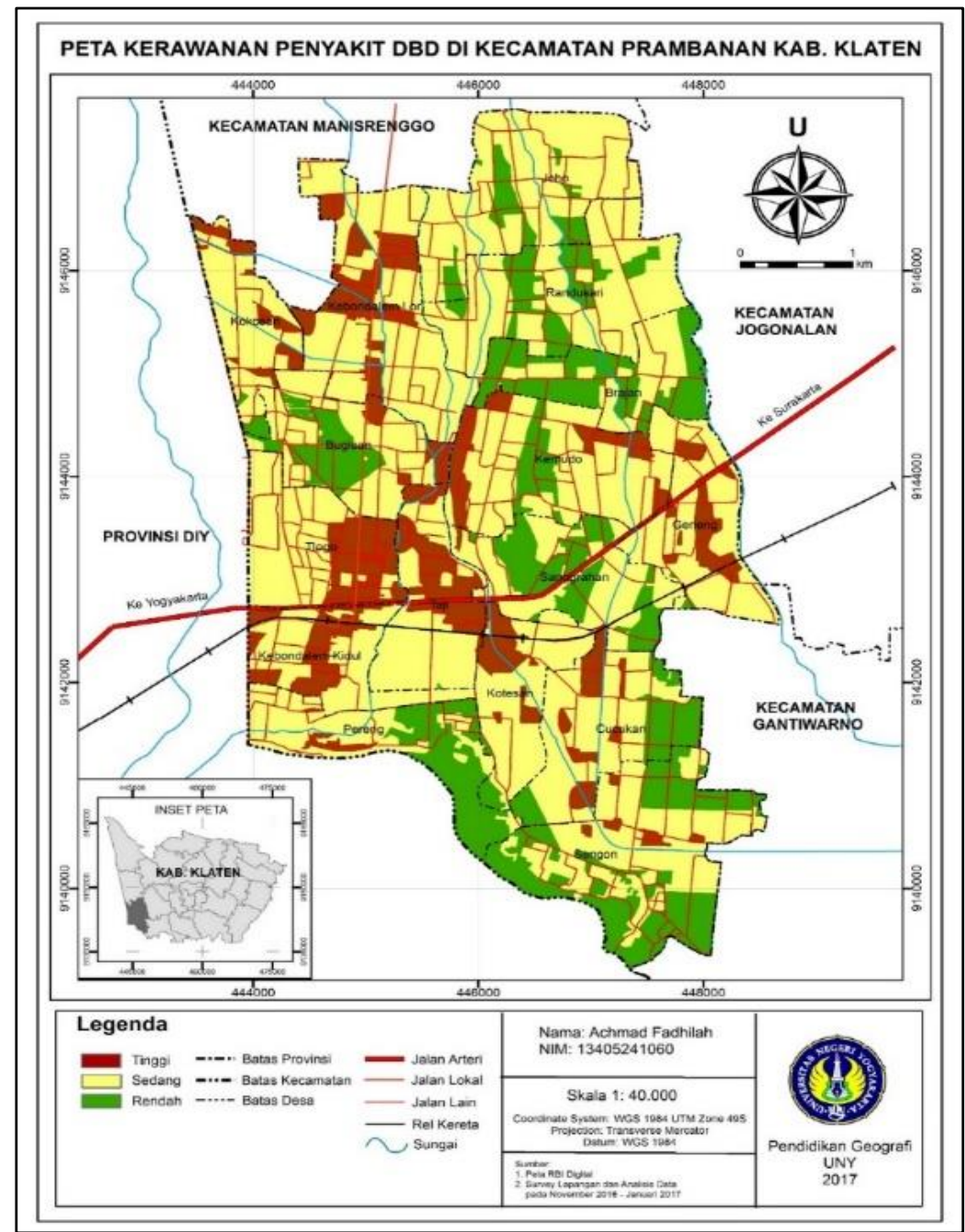

Gambar 3. Peta tingkat kerawanan DBD di Kecamatan Prambanan.

(Sumber: Hasil Analisis Data, 2017)

\section{Prioritas Lokasi Penanganan DBD di Kecamatan Prambanan}

Berdasarkan kondisi tingkat kejadian DBD dan persebaran tingkat kerawanan DBD, selanjutnya dapat dipertimbangkan prioritas dalam penanganan DBD di Kecamatan Prambanan, Kabupaten Klaten. Prioritas utama penanganan DBD di wilayah kerja Puskesmas Kebondalem Lor adalah Desa Kebondalem Lor. Desa Taji menjadi prioritas kedua, Desa Tlogo menjadi prioritas ke-3, dan Desa Kebondalem Kidul menjadi prioritas ke-4. Selanjutnya pada urutan ke 5 hingga 8 desa yang menjadi prioritas secara berturut adalah Desa Kokosan, Desa Kotesan, Desa Bugisan, dan Desa Joho. Sementara itu untuk wilayah kerja Puskesmas Prambanan Desa Kemudo merupakan desa yang menjadi prioritas pertama penanganan DBD. Desa Geneng menjadi prioritas kedua, Desa Cucukan menjadi prioritas ketiga. Selanjutnya Prioritas ke-4 hingga ke-8 berturut-turut adalah
Desa Sengon, Pereng, Sanggrahan, Randusari, dan Brajan.

\section{Prioritas Penanganan Berdasarkan Kerawanan DBD di Kecamatan Prambanan}

Untuk penanganan berdasarkan kerawanan DBD, terdapat dua jenis penanganan yang diprioritaskan yaitu Pemberantasan Sarang Nyamuk (PSN) dan menjaga kebersihan lingkungan. Hasil penelitian ini juga menunjukkan kesesuaian dengan prioritas tersebut yaitu terdapat daerah kerawanan DBD tinggi di Kecamatan Prambanan yang membutuhkan upaya Pemberantasan Sarang Nyamuk (PSN). Dengan upaya ini diharapkan potensi kejadian DBD dapat diminimalisir. Upaya penanganan DBD yang tidak direkomendasikan adalah fogging. Hal ini disebabkan karena fogging dapat menimbulkan bahaya bagi kesehatan pernafasan manusia. 
Berdasarkan wawancara dengan petugas kesehatan lingkungan Puskesmas Kebondalem Lor, karena sifat nyamuk yang mudah beradaptasi dengan lingkungan, maka kegiatan fogging ini menjadi kurang efetif dalam pemberantasan nyamuk Aedes aegypti. Sementara itu masih rendahnya kesadaran masyarakat dalam pencegahan DBD juga menyebabkan upaya sosialisasi atau penyuluhan tentang pencegahan DBD juga kurang efetif. Kegiatan penyuluhan sudah sering dilakukan oleh Puskesmas namun kurang direalisasikan oleh masyarakat. Oleh karena itu, upaya aksi langsung di lapangan melalui Pemberantasan Sarang Nyamuk (PSN) dan menjaga kebersihan lingkungan merupakan prioritas utama dalam penanganan DBD di Kecamatan Prambanan.

\section{Hubungan Curah Hujan Bulanan dengan Kejadian DBD di Kecamatan Prambanan}

Pada bagian sebelumnya telah disebutkan bahwa berdasarkan kejadian DBD menurut waktu, tidak terdapat gejala tingginya kejadian DBD pada waktu tertentu misalnya selama pergantian tahun ketika curah hujan tinggi. Untuk memperoleh hasil yang lebih akurat mengenai kemungkinan adanya keterkaitan antara curah hujan dengan jumlah kasus DBD di Kecamatan Prambanan digunakan analisis korelasi menggunakan fungsi scatter plot pada Ms. Excel.

itu analisis korelasi antara curah hujan bulanan tahun 2016 dengan kejadian DBD tahun 2016 memperoleh nilai $R^{2}$ sebesar 0,0127. (Gambar 4). Hal ini menunjukkan bahwa hampir tidak ada hubungan antara curah hujan bulanan dengan jumlah kejadian DBD masing-masing bulan pada tahun 2016. Data bulanan menunjukkan curah hujan yang relative sempit. $\mathrm{Hal}$ ini cenderung tidak memberikan pengaruh yang signifikan terhadap kejadian DBD. Kemungkinan kejadian DBD justru disebabkan oleh faktor-faktor lain. Kejadian DBD diawali dari adanya akumulasi air pada wadah, kemudian nyamuk bertelur, hingga akhirnya gigitan nyamuk pada manusia membutuhkan waktu yang relatif lama. Curah hujan yang tinggi pada bulan tertentu tidak selalu memengaruhi kejadian DBD pada bulan tersebut.

Sementara itu, hasil analisis antara curah hujan tahunan dari tahun 2012 hingga tahun 2016 dengan kejadian DBD dari tahun 2013 hingga 2016 memperoleh nilai $R^{2}$ sebesar 0,725 . Hal ini menunjukkan adanya hubungan yang positif dan signifikan antara besarnya hujan tahunan dengan kejadian DBD antara tahun 2012 hingga 2016.

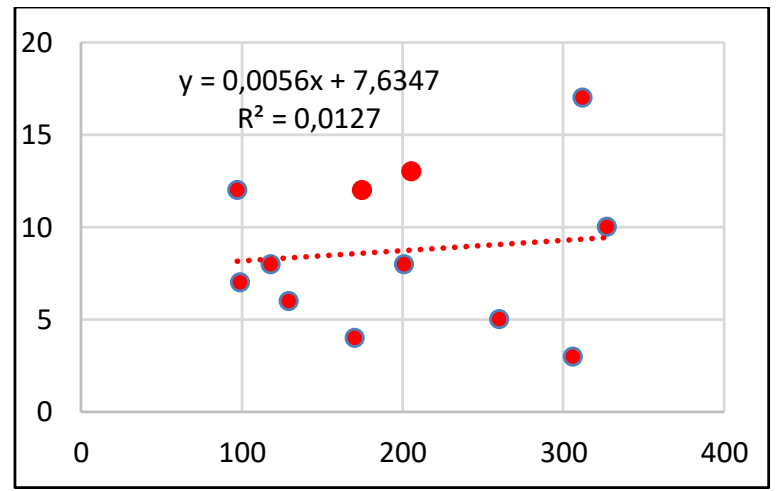

Gambar 4. Grafik hubungan antara curah hujan dengan jumlah kejadian DBD di Kecamatan Prambanan tahun 2013-2016. Variabel X merupakan data curah hujan tahunan 2012-2016, sedangkan variabel $Y$ merupakan data kejadian DBD 2013-2016.

\section{Simpulan}

Wilayah Kecamatan Prambanan Kabupaten Klaten memiliki area tingkat kerawanan DBD tinggi seluas 352,37 hektar atau $13 \%$ dari seluruh luas wilayah. Wilayah yang termasuk ke dalam area tingkat kerawanan DBD rendah memiliki luas 1809,55 hektar atau $66,85 \%$. Wilayah yang memiliki area tingkat kerawanan DBD sedang seluas 544,69 hektar atau 20,15\%. Desa yang menjadi prioritas utama dalam penanganan DBD di wilayah kerja Puskesmas Prambanan adalah Desa Kemudo. Desa yang menjadi prioritas utama di wilayah kerja Puskesmas Kebondalem Lor adalah Desa Kebondalem Lor. Jenis penanganan DBD yang diprioritaskan adalah Pemberantasan Sarang Nyamuk (PSN) dan menjaga kebersihan lingkungan.

\section{Ucapan terima kasih}

Dalam kesempatan ini penulis mengucapkan terimakasih kepada berbagai pihak yang telah membantu dalam penelitian ini, baik selama pengumpulan data maupun analisis data. Ucapan terima kasih secara khusus disampaikan kepada Ibu Dr. Dyah Respati Suryo Sumunar selaku dosen pembimbing atas masukan dan bimbingan dalam penyusunan tugas akhir skripsi maupun penyusunan artikel ini. Penulis juga mengucapkan terimakasih kepada Bapak Arif Ashari, M.Sc., yang telah memberikan masukkan dalam tulisan ini. 


\section{Referensi}

BPS Kabupaten Klaten. (2016). Kecamatan Prambanan dalam Angka 2015. Klaten: Badan Pusat Statistik Kabupaten Klaten

Dinkes Kab. Klaten. (2014). Profil Kesehatan Kabupaten Klaten tahun 2013. Klaten: Dinkes Kab. Klaten

Fathi., Keman, S., \& Wahyuni, C.U. (2005). Peran Faktor Lingkungan dan Perilaku Terhadap Penularan Demam Berdarah Dengue di Kota Mataram. Jurnal Kesehatan Lingkungan 2 (1), Retrived April 12, 2018 from http://id.portalgaruda.org/
McCoy, R.M. (2005). Field Methods in Remote Sensing. New York: The Guilfold Press

Prahasta, E. (2014). Sistem Informasi Geografis, Konsep-konsep Dasar Perspektif Geodesi dan Geomatika. Bandung: Penerbit Informatika

Sumarmo, S.P.S (1988). Demam Berdarah (Dengue) Pada Anak. Jakarta: UI Press.

Ucu, K.R. (2016). DBD Sasar Enam Kecamatan di Klaten. Retrived April 13, 2018, from http://nasional.republika.co.id/berita/nasion al/daerah/16/02/11/o2ckbf282-dbd-sasarenam-kecamatan-di-klaten. 